\title{
NIGERIA \\ Can the election tribunals satisfactorily resolve the disputes arising out of the 2003 elections?
}

\author{
By \\ Kaniye S A Ebeku*
}

Kaniye S A Ebeku LLM (LSE, London), PhD (Kent, England) is Senior Lecturer and Head of the Department of Jurisprudence and International Law, Faculty of Law,

Rivers State University of Science \& Technology, P.M.B. 5080, Port Harcourt, Rivers State Nigeria.

Tel: (+234) 8033171 815; e-mail: ksae2@hotmail.com

\section{INTRODUCTION}

Between April and May 2003 Nigeria held general elections to elect the country's President, state governors, and members of legislative houses at both national and state levels. The first election, held on 12 April 2003, was for National Assembly (the federal legislative house) members. This was followed by the presidential and governorship elections on 19 April 2003. Two dates - 26 and 29 April 2003 - were set aside for possible run-off elections (which did not happen). The last election, on 3 May 2003, was for members of the state houses of assembly (INEC 2003). In all, 30 political parties contested the election, although not all the parties fielded candidates for all the political offices. ${ }^{1}$

Remarkably, the 2003 elections were the first since the return to constitutional rule on 29 May 1999, after many years of military dictatorship. As will be seen below, many observers and commentators (both national and international) have condemned the elections for what some have called massive electoral frauds and malpractices. It was alleged that in many places in the country there was virtually no voting, yet 'results' were declared by the Independent National Electoral Commission (INEC) - a statutory body charged with the conduct of the elections. Consistent with the practice in other constitutional democracies and the provisions

The author wishes to acknowledge the contribution of Associate Professor CM Fombad of the Faculty of Law, University of Botswana, who read the first draft of this article and made useful suggestions. The author also wishes to acknowledge the editorial expertise of the editors of $J A E$, which greatly improved the general outlook of this article. However, the author is solely responsible for the opinion expressed in this article and for any remaining errors.

1 A record number of 20 candidates declared their interest in standing as President; 100 indicated interest in the 36 posts of governor; 500 stood for 109 senatorial slots, while 3000 candidates eyed 369 seats in the (Federal) House of Representatives. See reports at: http:/ / allafrica.com/stories/200303280571.html . 
of Nigerian electoral law, some aggrieved candidates and political parties challenged the results of the elections at various election tribunals set up under Nigerian electoral law.

Some challenged the election of President Olusegun Obasanjo; others contested those of some of the state governors (Nigeria is a federation of 36 states, each of which is under the governance of an executive governor). Essentially, most of the petitioners were asking for the nullification of the elections for various reasons, including electoral malpractice. With most of the cases still pending, a new government was sworn in on 29 May. Several court applications to stop the swearing-in failed, as courts across the country declined to issue restrictive orders. Despite this, some of the aggrieved persons (presidential, gubernatorial and legislative candidates) continued to pursue their cases in the appropriate election tribunal.

On 31 July 2003, the Court of Appeal, sitting in Port Harcourt, held that the decision of the Governorship and Legislative Houses Election Tribunal, which had thrown out the appeal of Chief Sergeant Awuse of the All Nigerian Peoples Party (ANPP) against the result of the governorship election of 19 April, had been wrong and ordered that the case be remitted to the tribunal for trial on the merits. ${ }^{2}$ Chief Awuse's petition challenged the election of Governor Odili of the People's Democratic Party (PDP) and asked that the election be nullified because of alleged electoral malpractices (the same relief Gen Mohammed Buhari, presidential candidate of the ANPP sought in his petition against the election of President Obasanjo of the PDP) ${ }^{3}$.

The critical question is whether an election tribunal can nullify the election of a serving officer of government and thereby remove him (particularly, the President of the Federation or the governor of a state) from office. A further, and more general, question is whether election tribunals can satisfactorily resolve the disputes arising out of the 2003 elections. These are important constitutional and political questions, which this paper attempts to answer. It should be pointed out, however, that this is not an attempt to inquire into the merits of any of the petitions brought before the election tribunals; rather, it is a general constitutional, statutory and political analysis based on the present state of Nigerian constitutional and statutory provisions as well as politico-constitutional issues arising out of the 2003 elections.

To accomplish the task set for this article, relevant provisions of the 1999 Constitution of Nigeria and the Electoral Act 4 of $2002^{4}$ will be examined. As a

$2 \quad$ See Chief Sergeant Awuse v Dr Peter Odili and Others (Unreported Suit No. CA/PH/EPT/154/2003, decided on 31 July 2003). The case is to be re-tried by a reconstituted election tribunal.

3 Another case, brought by the presidential candidate of the All Progressive Grand Alliance party (UPGA), Dim Chukwuemeka Odumegu Ojukwu, against the election of President Obasanjo on the grounds that he was not qualified to contest the election, was dismissed by the Presidential Election Tribunal in July 2003.

4 This Act has recently been amended by the Electoral Act 2003, although not in any way that might significantly affect the present inquiry. 
background, the reactions of various national and international observers (and commentators) who monitored the elections as well as those of some of the defeated candidates (before the filing of election petitions) to the conduct of the 2003 general elections in Nigeria and the results declared by INEC, will be set out briefly. Specifically, this will highlight the politico-constitutional issues involved in this inquiry.

\section{BACKGROUND AND CONTEXT \\ Reactions To The Conduct And Results of the 2003 GENERAL ELECTIONS}

The fact that the general elections in Nigeria were the first after the country's return to constitutionalism, coupled with the importance of the country as the most populous in Africa, probably accounts for the large number of national and international observers during the elections. Among these were human rights groups, the European Union Observer Group, the Commonwealth Observer Team, the Centre for Democracy and Development (CDD) Observer Team, the International Republican Institute Observer Team, and various observers from the United States. Since the end of the elections, and even before and during the elections, these groups have issued or made statements concerning the conduct and outcome of the elections. Some of their observations and conclusions are set out briefly below.

At a news conference after the declaration of the presidential election results, the European Union (EU) chief observer reported 'widespread irregularities in six states, mostly in the south and the east'. Among other malpractices, he alleged that there was 'ballot stuffing in the face of EU observers', perpetrated by the supporters and agents of President Obasanjo's party, the PDP. He further slammed the conduct of state-owned media companies, which 'failed to live up to their legal obligation to provide equal access and fair coverage of all political parties and demonstrated political bias in favour of the ruling parties at federal and State levels' $(<\mathrm{http}: / /$ portal.tds.net/news xml.php). In conclusion, he observed that 'the only way for elections to be free and fair was for Nigerians to question ballot stuffing and incidents of rigging' (< http://portal.tds.net/news xml.php and <http://www.cnn.com/ 2003/WORLD/africa/04/22/nigeria.election/ >). By implication, the EU observers concluded that the 2003 elections were not free and fair. This was also the conclusion of the International Republican Institute in its report, published a little earlier than that of the EU (<http://www.cnn.com/2003/WORLD/africa/04/22/ nigeria.election $/>$ ). The Commonwealth Observer Team observed that 'the election largely went well', although they cited a 'few incidents of violence'. In a statement signed by its leader, Salim Ahmed Salim, the team stated:

From the reports of our team, we know that in most of Nigeria a genuine and largely successful effort was made to enable the people to vote 
freely ... But in certain states, the election did not go well ... In parts of Enugu and in Rivers state proper electoral processes appear to have broken down and there was intimidation ... <http: / / www.cnn.com/2003/WORLD/africa/04/22/nigeria.election/ >

It has been observed that this statement 'appeared aimed at steering away from further disputes after arguments over Zimbabwe caused a damaging split in the organization' - the Commonwealth, a 54-nation group comprised mainly of former British colonial states (<http:/ / www.cnn.com/2003/WORLD/africa/04/22 / nigeria.election/ >). Whatever the reason for the statement it is consistent with others with regard to electoral malpractices in some states or areas of the Federation.

The observations and conclusions of the CDD, which deployed forty observers across the six zones of the country, concerned issues ranging from the preparation and conduct of the episodic elections to the results declared by INEC (CDD 2003). The importance of pre-election issues has been well explained, as follows:

Elections are not necessarily about election-day activities although it forms an important component. It encompasses activities before, during and after elections. It includes the legal and constitutional framework of elections, the registration of political parties, party campaigns, the activities of the electronic and print media in terms of access ... campaign financing, the activities of the security agencies and the government in power ... the authenticity and genuineness of the voters register [and]... the independence or lack of it of electoral agencies and organs ...

TMG 2003

Remarkably, this position holds true, not only for Nigeria but also for democratic traditions all over the world. Commenting on the conduct of elections in the context of Africa, Fombad (2003 pp 26-27) pertinently wrote:

Conventional accounts of the evolution of the electoral processes in Africa in the last decade have tended to focus on the voting processes on election-day or on the outcome of elections without paying much attention on who organized the elections, how they were conducted and the structure and processes put in place for doing this. The centrality of elections to the model of liberal democratic politics to which many African countries today aspire presupposes the existence of electoral institutions that will guarantee a free and fair contest. One of the key institutions essential to accomplishing this is an independent election management body (EMB) ... [In fact] the overall legitimacy and acceptability of an election depends on many factors, one of the most crucial of which is the integrity of the election management process ... Fundamental as they are, elections on their own are neither 
the sole means nor the exclusive end of democracy. They do provide a useful indicator of a country's democratic health.

It is against this background that the approach of the CDD should be viewed. The CDD observed that during the election candidates did not have equal access to the state-owned media. The power of incumbency dictated 'somewhat partisan coverage'.

For example, the official national website www.nopa.net became 'largely a campaign vehicle for the executive'. Moreover, in some parts of northern Nigeria it was observed that there was unequal access to, for instance, fuel. While incumbent governors had constant and regular supplies, this was not the case for opposition party campaigners. Furthermore, it was observed that in the period prior to the polls there was nowhere in the country where INEC successfully carried out the promised three-day exercise in which temporary registration slips were to be exchanged for voters' cards. 'This failure may have had effects later, in episodes in which we witnessed confusion over documentation by people attempting to vote, and more seriously, the continuing of the exercise into the polling days.' Even more seriously, the situation led to the possession of multiple voters' cards by nonregistered voters.

The CDD further observed that the incumbent administration deliberately released funds late to INEC for the conduct of the elections. This, it observes, coupled with the government's control over appointments of senior members of INEC, made 'INEC's independence of action less than complete'. Moreover, the late release of funds also compromised INEC's logistical effectiveness. On its part, INEC was blamed, among other things, for poor training of election officials and widespread neglect of the welfare of its own staff.

Interestingly, the incompetence and partiality of INEC was also noted by Rotimi Suberu (2003), a close watcher of the Nigerian political scene, shortly before the polls were conducted. He wrote:

The greatest source of anxiety regarding the forthcoming elections is neither ethnicity nor the moral bankruptcy of the major parties and political leaders, but the fragility of the agency that has been entrusted with the administration of the elections, namely, the Independent National Electoral Commission (INEC). Appointed and funded by the federal executive, INEC has been anything but truly independent. Rather, the Commission has demonstrated little competence or independence in the management of such issues as the registration of new political parties, the scheduling of the various rounds of federal and state executive and legislative elections, the compilation and publication of the voters' register, and the regulation of intraparty and inter-party relations. 
On the whole, the CDD found it 'hard to avoid the overall conclusion that the main concern of the incumbent government was not to run the most open election possible, but ... to use the advantages of its position to remain in power by whatever means ... possible ...' The election 'was far from free and fair' (CDD 2003).

The Washington-based National Democratic Institute said in its statement that in both the 12 April parliamentary elections and the 19 April presidential poll, 'instances of ballot stuffing, rigging, voter intimidation, violence and fraud ... were so acute in certain parts of the country, particularly the South South and South East regions, that we have serious concern about the legitimacy of the results in certain constituencies (EU 2003 and http://portal.tds.net/news xml.php > (last visited $\underline{06 / 09 / 03))^{\prime}}$.

In its own reaction, the United States stated that 'there were widespread and often credible claims of electoral malfeasance perpetrated during the National Assembly, Governorship and Presidential polls'. Consistent with the practice in the United States, State Department spokesman Richard Boucher urged aggrieved parties to 'present their evidence to the competent tribunals', and the tribunals to 'consider those complaints in a fair and transparent manner' (The Punch April 2003, p 3$)^{5}$

While the positions of the foregoing observer groups are clear, the position of the Transition Monitoring Group (TMG) (a coalition of 170 Nigeria-based human rights groups and civil society organisations) - who also monitored the 2003 elections - is rather ambivalent. In their interim report on the presidential and gubernatorial elections, they concluded that 'there were substantial flaws in some of the critical stages leading up to the elections which tended to undermine the credibility of the process'. In their final report they remarked that 'the reality of elections is not in doubt', and pertinently asked 'whether the elections, viewed holistically, can be said to be genuine elections aggregating the expressed wish of the people of Nigeria'. Furthermore, they asked whether the elections met 'minimum international and domestic standards that Nigeria as a country is committed to'.

Considering the questions raised, the group noted Nigeria's commitment to the New Partnership for Africa's Development (NEPAD), which commits the whole of Africa, including Nigeria, to 'respect the global standards of democracy, the core components of which include political pluralism ... and fair, open and democratic elections periodically organized to enable the people to choose their leaders freely', and further asked at this juncture: 'Can the 2003 elections pass the test of having enabled the Nigerian people to choose their leaders freely?' (TMG, p xii).

It is also notable that Nigeria is further committed to the Declaration on the Framework for an OAU Response to Unconstitutional Changes of Government (Assembly

The verdict of international and local observers/participants on Cameroon's elections since the 1980s (including the 1997 presidential election) was strikingly similar to those on Nigeria's 2003 elections. For example, international and local observers who had monitored the 2003 election reported that 'it was neither free nor fair'. For the account of this, see the incisive article by Charles M. Fombad: Fombad, pp $31-34$. 
of OAU Heads of States and Governments, 36th Session). Essentially, this Declaration proclaims a continent-wide commitment to democracy and attempts to give substance to that commitment by setting out 'common values and principles for democratic governance' in African countries (para 8). Specifically, it rejects any unconstitutional change in government as an anachronism and a contradiction of Africa's commitment 'to promote democratic principles and conditions' (para 4).

Furthermore, the Constitutive Act of the African Union (AU) (2000), of which Nigeria is a State Party, also provides that 'governments which shall come to power through unconstitutional means shall not be allowed to participate in the activities of the Union'.

Even more recently, Nigeria was party to the Declaration on the Principles Governing Democratic Elections in Africa (Assembly of OAU Heads of States and Government, 38th Session), which reaffirms the principles of democratic governance in earlier instruments and asserts, inter alia, that 'democratic elections should be conducted: (a) freely and fairly; (b) under democratic constitutions and in compliance with supportive legal instruments; (c) under a system of separation of powers that ensures in particular, the independence of the judiciary; (d) at regular intervals, as provided in national constitutions; [and] (e) by impartial, all-inclusive competent accountable electoral institutions staffed by well-trained personnel and equipped with adequate logistics.'

Regrettably, however, none of the various questions raised by the TMG received any definite and final positive or negative answer (TMG, chapter 8; National Democratic Institute and the Carter Centre 2003).

Many observers who witnessed the public presentation of the final report were disappointed with the non-committal position of the TMG. For example, Emma Ezeazu, former president of the National Association of Nigerian Students (NANS), remarked that the 'watered down' position of the TMG 'did not really take account of the gravity of the alleged frauds that were perpetrated during the elections'. He faulted the TMG for 'failing categorically to denounce the polls'. Representatives of opposition parties also condemned the TMG's final report for its ambivalent position (The Guardian August 2003, pp 8-9).

The comments of some 'defeated' candidates were similar to the observations of the monitors. The comments of the presidential candidate from the ANPP and the ANPP candidate for governorship of Rivers State are representative of views across the spectrum. According to the presidential candidate, Gen Buhari, the presidential election was 'the most fraudulent Nigeria has ever had since independence ...This would be the first election in which ballot boxes were forcibly removed, with some security agents openly collaborating. This would be the first election in which, through elaborate collusion, those who lost elections were declared winners and those who won, lost' (The Punch, 24 April 2003, p 2).

For his part, the ANPP governorship candidate for Rivers State, Sergeant Awuse, alleged that 'no elections were held in Rivers State' and that 'the victory of the PDP is a stolen mandate that cannot stand'. He further stated that he, his 
supporters and his party 'are grateful to the international observers and the media who have exposed the brutal disenfranchisement of the people that took place in Rivers State during the ... elections', and declared his resolve to contest the result at the appropriate election tribunal (The Argus, p 2), which he did.

Although, as stated earlier, it is not intended to consider the merits of the petitions brought before the various election tribunals, it is noteworthy that the complaints against the conduct of the 2003 elections are largely reflected in the various petitions filed before tribunals nationwide (Nigerian Newspapers online 2003). Even so, this is only to the extent that they are within the statutory grounds for questioning the results of the elections (see below).

\section{Basic Constitutional Provisions}

The basic constitutional provisions relevant to this analysis include sections 1, 135, 139, 143, 180, 188, and 285 of the Constitution of the Federal Republic of Nigeria 1999. Section 1 provides, inter alia:

(1) This Constitution is supreme and its provisions shall have binding force on all authorities and persons throughout the Federal Republic of Nigeria.

(2) The Federal Republic of Nigeria shall not be governed, nor shall any person or group of persons take control of the Government of Nigeria or any part thereof, except in accordance with the provisions of this Constitution.

This provision does not differ from s 1(1) and (2) of the 1979 Constitution of Nigeria. Commenting on the rational for section 1(2), Akande says that 'this subsection is presumably a reassertion of the illegality of revolutions or coups d'état as a means of changing governments', although it is doubtful whether the legality of any coup can be successfully challenged through this provision (Akande 1982, p 2). ${ }^{6}$ While s $1(2)$ is probably aimed primarily at preventing the phenomenon of coups in Nigeria 7 , it is arguable that any change of government by an electoral process which does not accord with the spirit and intention of the Constitution (for instance, because of flawed electoral processes) is equally forbidden by this subsection. The Constitution provides for change of government every four years by free and fair

6 The author did not repeat this view exactly in her subsequent book on Nigerian constitutional law. However, she points out that 'when a military coup occurs, the regime legitimizes itself by suspending the Constitution, and from then its legality no longer depends on any Constitution but on Decrees enacted by itself'. This is probably another way of expressing doubts about the utility of the provision (Akanda 2000, p 16).

7 There have been several military coups in Nigeria since the trail blazer of 1966, with the result that since independence in 1960 Nigeria has been ruled more by military dictators than by democratically elected leaders. 
elections, and not by any other means. Hence, any person who comes into political office through a flawed electoral process (for want of better expression, this may be described as 'purported election') may be said to be governing Nigeria or controlling the government of Nigeria in defiance of the provisions of the Constitution.

Sections 135 and 180 respectively deal with the tenure of office of a person elected and sworn into office as President of the Federation of Nigeria and as governor of a state of the Federation. According to these sections, the President and governors shall be in office for a period of four years, commencing from the date when they took the oath of allegiance and the oath of office. The incumbent President or governor must vacate office when his or her successor takes the oath of allegiance and oath of office (or would, but for his death, have taken such oaths) (ss 135 (2) and $180(2)$ ).

In addition to laying down a four-year term of office, the Constitution provides for circumstances in which the office is prematurely vacated. Among these circumstances are the death in office of a serving President or governor; the resignation of the President or governor; and the removal from office of a President or governor by impeachment or because of an incapacity which permanently renders him or her incapable of discharging the functions of the office. The last two situations involve elaborate constitutionally prescribed procedures.

In the case of impeachment of the President of the Federation (s 143) the process starts with the presentation of a notice of allegation of 'gross misconduct' to the President of Senate (the upper federal legislative chamber in Nigeria). In the case of impeachment of the governor of a state (Constitution 1999, s 188) the notice must go to the Speaker of the State House of Assembly. (For the present purpose, only the impeachment procedure of the President of the Federation will be considered, since the same procedure is prescribed for that of a state governor.)

The notice must be signed by not less than one-third of the members of the National Assembly (the Senate and House of Representatives). Upon receipt of such notice, the President of Senate shall, within seven days, cause the notice to be served on the holder of the office and on each member of the National Assembly. If the holder of the office responds the President of Senate shall distribute the response to each member of the National Assembly (s 143(2)).

The Constitution requires that within fourteen days of the date of presentation of a notice of impeachment (regardless of whether any reply has been given by the holder of the office) each House of the National Assembly shall resolve by motion (without any debate) whether to investigate the allegation contained in the notice (s 143(3)). Such a motion shall not be regarded as having been passed unless it is supported by the votes of at least a two-thirds majority of all the members of each house of the National Assembly (s 143(4)). Following a proper motion, the Chief Justice of Nigeria shall (at the request of the President of Senate) appoint a panel of seven persons to investigate the allegation. Members of the panel shall not be members of any public service, legislative house or political party, and shall be 
persons who, in the opinion of the Chief Justice of Nigeria, are of unquestionable integrity. The panel has three months from the date of its appointment to report its findings to each house of the National Assembly (s 143(7)(b)). If the panel finds that the allegation has not been proved, the matter ends (s 143(8)). Where, however, the panel's report shows that the allegation has been proved, each house of the National Assembly must, within fourteen days, consider the report, and if the report is adopted by at least two-thirds of the members of the House, the holder of the office shall stand removed from office as from the date of the adoption of the report (s 143(9)).

It is notable that under s 143(11) of the Constitution, 'gross misconduct' as a ground for premature removal of a serving President from office means 'a grave violation or breach of the provisions of the Constitution or a misconduct of such a nature as amounts in the opinion of the National Assembly to gross misconduct' (see also s 188(11)).

With regard to premature removal from office on the ground of permanent incapacity, the Constitution requires a resolution declaring that the President (or governor, in the case of a state government) is incapable of discharging the functions of his office to be passed by a two-thirds majority of all members of the executive council of the Federation (ie, the body of ministers of the government of the Federation (s 144(5)). In the case of a state, the requirement relates to the body of commissioners of the government of the state (s 189(5)). ${ }^{8}$ Following this, a medical panel may be appointed by the President of Senate to verify the claim of permanent incapacity. If it does so, a notice must be signed by the President of Senate and the Speaker of the House of Representatives and published in the official Gazette. On the date of publication the President shall cease to hold office. .

These are the only occasions when a serving President or state governor may vacate office prematurely. There is no constitutional provision for the premature removal of the occupant of such office by any court of law or tribunal.

\section{Constitutional Provisions AND JURISDiction of Election TRibunals}

There are both constitutional and statutory provisions dealing with the establishment and jurisdiction or powers of election tribunals. ${ }^{9}$ Section 285 of the 1999 Constitution provides for the establishment of National Assembly election tribunals (s 285(1)), and governorship and legislative houses election tribunals (s 285(2)). The former have original jurisdiction, to the exclusion of any other court or tribunal, to hear and determine petitions relating to: whether (a) any person has been validly elected as a member of the National Assembly; (b) the term of office of

$8 \quad$ For equivalent provisions relating to state governors, see s 189.

9 The tribunals are ad hoc courts, which are constituted to deal with election petitions and cease to exist after the conclusion of the petitions. 
any person under the Constitution has ceased; (c) the seat of a member of the Senate or a member of the House of Representatives has become vacant; and (d) a question or petition brought before the election tribunal has been properly or improperly brought (s285(1)). On the other hand, the latter has exclusive original jurisdiction to hear and determine petitions relating to whether any person has been validly elected to the office of governor or as a member of any legislative house (referring to a state House of Assembly) (s 285(2)). In all, there are thirty-six National Assembly election tribunals and thirty-six governorship and legislative houses election tribunals nation-wide - one each in each of the thirty-six states of the Federation.

To be sure, although the offices of legislators at both federal and state level are important, the offices of President of the Federation and governor of a state of the Federation, being the most important constitutional-political offices in the country, will be the focus of this inquiry and the elections to these offices will be used to examine the issues involved.

In the case of presidential elections, the Court of Appeal acts as the election tribunal and operates only in the Federal Capital Territory, Abuja. Under s 239(1) of the Constitution, it has original jurisdiction (to the exclusion of any other court of law in Nigeria) to hear and determine whether any person has been validly elected to the office of President of Nigeria; or the term of office of the President has ceased; or the office of President has become vacant.

These constitutional provisions are supplemented by the provisions of the Electoral Act 2002. The Act describes an 'election petition' as one complaining of an 'undue election' or 'undue return', presented to the competent tribunal/court (see above) in accordance with the Constitution and / or the provisions of the Act (s 131(1)). A petition may be brought by a candidate or a political party that participated in the election on any (and no other) of the following grounds:

(a) That a person whose election is questioned was, at the time of the election, not qualified to contest the election.

(b) That the election was invalid by reason of corrupt practices or noncompliance with the provisions of the Electoral Act.

(c) That the respondent was not duly elected by majority of lawful votes cast during the election.

(d) That the petitioner or its candidate was validly nominated but was unlawfully excluded from the election.

It is notable that the issue of jurisdiction is as important in election petition cases as it is in cases brought before the regular courts of the country. In Sanyaolu $v$ INEC ([1999] 7 NWLR (Pt. 612) 600, at 608), it was held that the jurisdiction of an election tribunal, like that of any other judicial body, is limited to what it is constitutionally and/or statutorily empowered to do. The result is that any petition that is not brought under any of the above grounds is incompetent and the election tribunal before which it is brought has no jurisdiction to entertain it (see below). 
Under s 136(1) of the Electoral Act 2002, but subject to s 136(2), if an election tribunal determines on any grounds that a candidate who was returned as elected was not validly elected, it shall nullify the election (s 136(1)). Where, however, it determines that a candidate who was returned as elected was not validly elected, on the grounds that he or she did not win the majority of valid votes cast in the election, it shall declare as elected the candidate who won the highest number of valid votes and satisfied the requirements of the relevant constitutional and statutory provisions (s 136(2)).

Perhaps as a means of avoiding a vacuum in (high) political office, s 138 of the Electoral Act provides that where an election tribunal has determined that a candidate returned as elected was not validly elected, he or she shall nonetheless remain in office pending the determination of an appeal, if the appeal is lodged within 21 days of such determination (s 138(1)). Where an appeal has not been lodged, the candidate shall still remain in office pending the expiration of the 21 days within which an appeal may be brought (s 138(2)).

Significantly, s 138 appears to contemplate a situation where an election petition may be pending and the person whose election is being challenged is sworn into office (as happened on 29 May 2003 with the swearing in of President Obasanjo and the governors of the thirty-six states of the Federation, some of whom, like President Obasanjo, have petitions against their election pending before various election tribunals. In this regard, it can be argued that the courts / election tribunals which declined to issue an injunction to prevent the swearing in of President Obasanjo and the governors of some states, pending the determination of election petitions against them, were right. ${ }^{10}$ In fact, in Asin $v$ Orubu $\mathcal{E}$ others ([1989] 2 N.E.P.L.R. 14, at p. 22), the Court of Appeal (which has a country-wide appellate jurisdiction and is immediately below the Supreme Court of Nigeria in the judicial hierarchy) considered a similar provision under a former Local Government electoral law - the Local Government Election Decree (No 37 of 1987), and rationalised it thus:

After all, the maxim is: omnia praesumuntur rite esse. Until the petitioner/ respondent has discharged the onus on him to prove that the appellant was not duly elected, the latter ought not ordinarily be deprived of his seat to which he had been returned elected ... The learned trial Judge gave no consideration whatsoever to the desirability, in the public interest, of there being a Chairman for the Local Government functioning pending the determination of the petition before him. Had he given due consideration to section 37 of Decree No. 37 of 1987

$\overline{10} \quad$ Electronic and print media sources reported that several cases were brought before regular courts and before some election tribunals to restrain various elected candidates, including President Obasanjo and Governor Peter Odili of Rivers State, from being sworn into office pending the determination of petitions brought against their returns as duly elected candidates. None of the applications was successful. 
[similar to section 138 of the Electoral Act 2002] he would not have made the order of injunction he made ... Except in exceptional circumstance ... trial courts should be wary indeed in granting injunctions restraining a candidate returned elected from functioning or taking his seat unless and until such a candidate's election have (sic) been avoided on the determination of the petition brought challenging it. (Emphasis added)

Even so, the critical question that arises from s 138 is whether a President or governor who did not appeal an adverse decision of an election tribunal or who lost an appeal ceases to hold office without any further action, such as a judicial action, to remove him from office. A literal or natural interpretation of this section seems to indicate that the answer is in the affirmative. But this is not the end of the problem. A further question is whether this premature 'removal' is within the contemplation of the Constitution, which is superior to the Electoral Act. Sections 143 and 144 of the Constitution (see above) read with s 146(1) of the Constitution (dealing with situations where the Vice-President of the federation may succeed to the office of President $)^{11}$ indicate that the Constitution intends to provide exhaustive situations when a President may be prematurely removed from office. In the result, 'removal' under s 138 of the Electoral Act would appear be unconstitutional, null, void and of no effect. In other words, it cannot operate to cause the occupant of the office to cease functioning in that office. The logical conclusion here is that a pending election petition implicitly abates from the date the person whose election as President or governor is being contested is sworn into office. In which case, every effort and / or resource committed to the continuance of the petition thereafter is wasted.

While this position may be constitutionally sound under the provisions of ss 143, 144 and 146, one question remains: Can a person whose election has been nullified by an election tribunal or the Court of Appeal, but who continues in office (especially after 21 days) be said to be holding office in accordance with the Constitution, as required under section 1(2) of the Constitution? As already argued, the Constitution (and even the Electoral Act) contemplates a free and fair election (in the language of the Electoral Act, a 'due election' or 'due return') (s131(1)). As explained by the Court of Appeal in Ezeobi v Nzeka ([1989] 1 NWLR (Pt. 98) 478), (where the petitioner alleged that the respondent's return at the election in which he was a candidate was undue) 'for any election of a person to be undue, it must of necessity be unmerited, improper, not rightful, undeserved or inappropriate because of a variety of reasons'. By implication, an 'undue election' or 'undue return' is invalid $a b$ initio, and its nullification by an election tribunal or a court merely formalises the invalidity. Arguably, a person who holds office because of an invalid

11 Note that if a presidential election is validly nullified by the election tribunal, this affects the Vice-President as well, since they contested the election under one ticket. In this situation, the offices of President and Vice-President would be vacant and it would be an occasion for the President of Senate to assume the office of President pursuant to s 146(2). 
election cannot strictly be said to be holding office in accordance with the Constitution, as noted above. Unfortunately, the Constitution does not provide any explicit remedy in this kind of situation.

Perhaps it may be possible to bring an action for a declaratory relief under $\mathrm{s}$ 1(1) and (2) of the Constitution - to the effect that such person's occupation of office is unconstitutional, although the issue of locus standi and/or constitutional immunity may scuttle such an action. Specifically, on the issue of locus standi, the question might be whether the person who brings the action is competent to bring it - what is his or her personal interest in the matter? The question may arise because the election tribunal having completed its assignment, any action for declaratory relief as explained here will not be an election petition nor will it be cognisable under the Electoral Act, which sets out persons who may bring an election petition.

More importantly, the question of the competence of such a civil action might involve the issue of constitutional immunity. Under the 1999 Constitution (as under the 1979 Constitution, which it replaced) it is not permissible to bring a civil or criminal action against an incumbent President or governor (the same is true of Vice-President and deputy governor) during his or her period of office (s 308). The rationale for this was explained by Nwabueze (1982), thus:

The protection is essentially for the office, not of the individual incumbent as such. It is the majesty and dignity of the nation that is at stake. To drag an incumbent President [or governor] to court and expose him to the process of examination and cross-examination cannot but degrade the office. The interest of the nation in the preservation of the integrity of its highest office should outweigh any objections to the immunity.

p 81

It is remarkable that this is one area where the Nigerian Constitution departs from that of the United States of America from which it was copied. Under the American Constitution, it is held that every citizen is equal and granting immunity from suits to the President and state governors would amount to placing them above the Constitution. In the case of State of Ohio v Governor Salmon P. Chase 12.5 Ohio St.529, Chief Justice Bartley, in granting a mandamus against a state governor, stated: 'No officer is placed above the restraining authority, which is truly said to be universal in its behests, all paying it homage, the least as feeling its care, and the greatest as not being exempt from its power.'

Although it has been held in Sampson Itegbe $v$ Awa ([1989] 2 N.E.L.R. 92) that an election petition is not a civil proceeding but a suit sui generis, it must be remembered that declaratory relief of the nature explained here is not an election petition, but purely a civil action within the contemplation of s 308 of the Constitution. Even if it is held to the contrary and a declaration of unconstitutionality is made under s 1(2) of the Constitution, it is doubtful if it can operate to remove 
the affected officer from office, especially having regard to the arguments advanced above. Hence, there is certainly a serious constitutional problem here - a yawning gap. Apart from the constitutional issue, such a situation may well generate mammoth political problems in the country, as opposition parties and their supporters may become lawless and disruptive. It is notable that these problems will not arise if the President-elect or governor-elect has not been sworn into office, for then the 'constitutional protection' will not apply.

Apart from the foregoing problems, it is remarkable that the tribunals have no jurisdiction to consider issues which are not brought under or related to the statutorily-prescribed grounds for questioning the results of an election, as stated above. More specifically, the election tribunals have no competence to consider pre-election issues such as the authenticity of the voters' register; activities of the incumbent government and security agencies that give advantage to the incumbent government; unequal access of opposition parties during election campaigns to state-owned or state-controlled electronic and print media, giving advantage to the incumbent government; and the lack of independence of the INEC - issues which may have adversely affected the outcome of the elections, as alleged by opposition candidates and by various national and international monitors (see above).

In Princess Iduoze v Benedict Ogbeifun ([1989] 3 N.E.P.L.R. 98, esp at p 107), where the petitioner raised a pre-election issue in a petition brought under a former local government electoral law - the Local Government (Basic Constitutional and Transitional) Provisions Decree, No 15 of 1989 - the Court of Appeal categorically held that 'the events or incidents preceding the election, like inter-party disputes or other matters, are not matters that can be properly brought in a petition before the election tribunal', as its jurisdiction is confined to issues enumerated under the relevant law. The court emphasised that, strictly speaking, the tribunal's duty is "confined to considering "undue election" and "undue return" during the election exercise'.

This judicial decision is consistent with the provisions of the present electoral law. As one commentator has rightly observed, the election tribunals 'are in law set up to deal with matters arising out of complaints over an election. They are not concerned with disputes arising before the election' (Babalola 2003, p 48). The implication of this is that there is no forum, under the Constitution and the present Nigerian electoral law, for aggrieved candidates and their supporters to ventilate some of their fundamental grievances about the 2003 elections and seek redress. Besides, it has also been alleged that the election tribunals, appointed by the incumbent government, are not independent/impartial dispute resolution bodies. This was one of the reasons given by some defeated and aggrieved candidates for not bringing petitions before the tribunals, apart from the financial costs of prosecuting the petitions after expensive election campaigns. ${ }^{12}$

12 See reports in Nigerian newspapers online from April 2003 (available at: $\leq$ www.nigeriaworld.com $>$ ). 
On the whole, and very seriously, whatever the outcome of the petitions brought before the tribunals (especially where the tribunals hold against the petitioners), the view of various national and international observers as well as of some defeated candidates and their supporters that the 2003 elections were not free and fair is unlikely to change. This means that the government will remain illegitimate in the eyes of many people throughout its tenure.

\section{CONCLUSION}

The 2003 elections in Nigeria have raised important constitutional and political questions. One of these is whether election tribunals have powers effectively to redress the grievances of defeated candidates who come before them as well as the concerns of international and local election monitors. More specifically, the question is whether election tribunals can remove from office elected officials (particularly the President of the Federation or the governor of a state) whose elections are adjudged to have been marred by electoral malpractice. This question has arisen because these officials have been sworn into office before the conclusion of the adjudicatory processes and, by virtue of assumption of office, they become protected by constitutional provisions (as seen above). The analysis here has shown that Nigeria's present Electoral Act contemplates a situation in which an elected person whose election is being contested before an election tribunal, is sworn into office. Yet there is no constitutional or statutory provision by which he may be forced to vacate office if the election tribunal nullifies the election (in fact, any such statutory provision may be held to be unconstitutional if it cannot be supported by a constitutional provision). To be sure, the present Constitution provides exhaustive circumstances in which an elected President or state governor who has been sworn into office may vacate office prematurely, but these do not include nullification of the election by an election tribunal. In such a situation, it is debatable whether the person can be said to be holding office 'in accordance with the Constitution'. In any case, such a situation has the potential to precipitate a serious political and constitutional crisis in the country.

Apart from this problem, it has also been shown that election tribunals have no jurisdiction to entertain and determine pre-election issues, notwithstanding their adverse impact on the outcome of the elections - a situation that is a politicoconstitutional time bomb, as bottled angers may explode into a constitutional and political crisis in the country. Besides, the international community may well treat the persons holding political offices under such disputable circumstances with contempt, which may result in international isolation and the attendant economic consequences to the nation. ${ }^{15}$

On the whole, whether with regard to disputed issues over which they have jurisdiction or with regard to issues excluded from their jurisdiction, the election tribunals are unlikely satisfactorily to resolve the disputes arising from Nigeria's 2003 elections. 
There is here obviously a constitutional and/or statutory inadequacy, which can be remedied by appropriate amendments that require the conclusion of elections and election petitions well before a new government is inaugurated. This will obviate a situation where constitutional provisions may render an order of nullification of an election ineffective, with possible attendant politico-constitutional consequences. Further, the Constitution should explicitly provide that where for any reason an election petition cannot be concluded before a person elected as President or governor is sworn into office, he or she shall vacate office if the election is nullified by an election tribunal, and an interim government should be formed by a constitutionally-prescribed process, pending another election within a period not exceeding three months. Finally, the 2002 Electoral Act should be amended to give jurisdiction to election tribunals to consider pre-election issues, since the question whether an election or return was 'due' or 'undue' cannot be satisfactorily answered without considering pre-election issues directly related thereto.

15 In this regard, it is remarkable that the reactions of the international community since the conclusion of the elections have been somewhat contradictory. Notwithstanding the general condemnations of the elections by monitors from various counties, and particularly from Europe and the United States of America, the governments of these countries were quick to congratulate President Obasanjo on what some have called a 'well-deserved victory', and have since engaged in a flurry of diplomatic activity with Nigeria since then - the implication of which is an approval of all that has happened, notwithstanding outstanding disputes on the issues in the country.

This contrasts with the position in Zimbabwe, where, for reasons that may not be entirely related to the fairness of the electoral process that retained Mugabe as President, European countries and the United States of America have consistently condemned the presidential election and isolated the country. Is it that, in relating to various countries in Africa, developed countries are considering issues, perhaps economic, other than the need to promote democratic principles? In any case, African countries are no less guilty in this regard. Most of them also hurriedly joined in congratulating President Obasanjo on winning a second term in office, notwithstanding the outstanding queries, and have actively engaged in diplomatic contact with Nigeria since then. Yet, by various regional instruments, including the most recent African Union Constitutive Act, Nigeria is bound to observe democratic principles (including fairness in electoral processes). Surely, this kind of contradiction cannot augur well for the development of democracy in Nigeria, and, indeed, in Africa? 


\section{- REFERENCES -}

\section{Publications}

Akande, Jadesola O. 1982. Introduction to the Constitution of the Federal Republic of Nigeria 1979. London: Sweet \& Maxwell.

- 2000. Introduction to the Constitution of the Federal Republic of Nigeria 1999. Lagos: MIJ Publishers.

Babalola, Afe. 2003. Election Law and Practice. Ibadan: Intec Limited.

Fombad, Charles Manga. 2003. 'Election Management Bodies in Africa: Cameroon's National Elections Observatory in Perspective'. African Human Rights Law Journal 3(1).

Independent National Electoral Commission (INEC). 2003. 'Election Calendar' Reproduced in INEC. Manual for Election Officials. Abuja: INEC, 2003.

Nwabueze, B O. 1982. The Presidential Constitution of Nigeria. London: C. Hurst \& Company.

The Argus. 'Awuse to drag Odili to Election Tribunal'. Vol. 2(35).

The Guardian. 2003. 'Election 2007: Monitors, Stakeholders call for early preparation', 27 August.

The Punch. 2003. 'Poll: Go to tribunal, US tells aggrieved parties', 24 April.

Transition Monitoring Group (TMG). 2003. Do the Votes Count? Final report. Abuja: TMG.

\section{Websites}

Assembly of Heads of State and Government, 36th Ord. Sess., O.A.U. Doc. AHG/ Decl 5 (XXXVI), Lome, Togo (2000), (available at: http:/ / www.iss.co.za/AF / RegOrg/unity/pdfs/oau/hog/10HoGAssembly2000.pdf ).

Assembly of Heads of State and Government, 38th Ord. Sess., O.A.U. Doc. AHG/ Decl 1 (XXXVIII), Durban, South Africa (2002) (available at: http:// www.africa-union.org/en/commpub.asp?ID=106).

CDD. Summary Report on Nigeria's 2003 Elections. http://www.cdd.org.uk/ nigeria election analysis 2003.htm $>$.

Constitutive Act of the African Union, July 2000, CAB/LEG/23.15 (entered into force on 26 May 2002), art. 30 (available at: http:/ / www.au2002.gov.za/ docs / key oau/au act.pdf).

'EU Slams Nigeria's "rigged" Elections'. $\leq$ http:// portal.tds.net/news xml.php. 'Incumbent Obasanjo declared winner'. <http:/ / www.cnn.com/2003/WORLD/ africa $/ 04 / 22 /$ nigeria.election $/>$.

$\leq$ http://www.cdd.org.uk/nigeria election analysis 2003.htm >.

National Democratic Institute and the Carter Center. The 2003 Nigerian Electoral Process: Second Report.

http: / / www.cartercenter.org/ viewdoc.asp?docID=1269\&submenu=news. 
Nigerian Newspapers online. www.nigeriaworld.com.

Suberu, Rotimi T. 2003. 'Can Nigeria Muddle through the April 2003 Elections?' http:// site.www.umb.edu/forum/1/Dispute Resolution/res/nigeria/ Personal Web Page.htm>. 